\title{
The Politics of Tragedy in the Dutch Republic: Joachim Oudaen's Martyr Drama in Context
}

\author{
Nigel Smith
}

In this essay I make a case for the significance of the drama of Joachim Oudaen, Remonstrant, Collegiant and republican in the Dutch Republic, who is more well known for his hymns, his Socinianism, and his occasional controversial or patriotic pamphlets. I look at two plays in particular-Haagsche Broeder-Moord, Of Dolle Blydschap (Fratricide at The Hague, or Mad Joy, 1673), and Servetus (1655) — considering them as political and religious dramas both informed by and attempting to shape the understanding of key violent events in the history of the Dutch Republic and post-Reformation European religion. Oudaen appears in recent histories as a source of critical views regarding the princes of Orange and patriotic sentiment against the English during the Anglo-Dutch wars of $1664-1667$ and $1672-1674$. Some of his non-dramatic writing has drawn the attention of art historians, but his plays have received very little attention even in the world of Dutch literary scholarship, and in the English-speaking world this corpus is entirely unknown. Before we approach the author and his plays, here are some important considerations of context.

\section{$\mathbf{1}$ \\ Literature and the Rise of the Dutch Republic}

The distinctiveness of the early modern Dutch Republic, the Republiek der Zeven Verenigde Provinciën (Republic of the Seven United Provinces) is well attested in historiography. It was a newly formed state, emergent from a religious and political revolt in the 1570s against Spain, with whom there would be a military conflict lasting eighty years. Partly in order to fund resistance to Spain the United Provinces developed a global commercial empire and a political economy unrivalled through the seventeenth century. ${ }^{1}$ The conse-

1 Among the many studies dealing with the rise of the Dutch Republic, and reaching back to the seventeenth century, see in particular Jonathan Israel, The Dutch Republic: Its Rise, Greatness and Fall, 1477-1806 (Oxford: Clarendon Press, 1995). For an integrated view of the relationship between political structure and cultural and artistic consequences, see Horst 
quence was a cultural life dedicated to understanding and promulgating the nature of the new political reality and society that had been created, coupled with a measure of lament for that which had been lost. The republic's chief sociological feature was an unusually open and collaborative civil society. Some of its many writers were members of a group that met at the Muiderslot—home of the poet P.C. Hooft (1581-1647)—outside Amsterdam, an association that was notably cross-class as well as open to female participation. The idea of a 'Muiden group' has been seen as nineteenth-century mythmaking, but the exchange of correspondence in letters and through poems suggests a literary circle that lasted for a very long time and encompassed a remarkably broad social range, from neo-aristocratic state officials (Hooft; Constantijn Huygens, 1596-1687) and merchants (Roemer Visscher, 1547-1620) to painters (Gerbrand Adriaenszoon Bredero, 1585-1618), shopkeepers (Joost van den Vondel, 1587-1679), and glaziers (Jan Vos, c. 1610-1667). ${ }^{2}$ Women writers - notably the daughters of Visscher, Anna Roemers Visscher (c. 1584-1651) and Maria Tesselschade Roemers Visscher (1594-1649)—played influential roles that were politically and religiously committed. The coalescence of craft and literary ability was crucial: Dutch writers were moonlighters. For example, Jan Vos, well born but a successful glazier (he furnished the New Town Hall with its glass), was also a playwright and a poet; he was also so popular as a dining companion that he was known as the 'family poet' - with dinner often came an occasional poem. ${ }^{3}$

Lademacher, Phönix aus der Asche?: Politik und Kultur der niederländischen Republik im Europa des 17. Jahrhunderts (Münster: Waxmann, 2007).

2 See Jacobus Scheltema, Anna en Maria Tesselschade, de dochters van Roemer Visscher: In eene redevoering, waar achter aanmerkingen en bijvoegsels: opgedragen aan de Nederlandsche vrouwen (Amsterdam: J.W. Yntema en comp, 1808); Adriaan Beeloo, Maria Tesselschade Visscher, op het slot te Muiden: blijspel (Amsterdam, [c. 1819]); J. van Vloten, Tesselschade Roemers en hare vrienden in 1632-1649 (onuitgegeven brieven en dichtjens van Tesselschade, Huygens, Van Baerle) (Leiden: Brill, 1852); M.C.A. van der Heijden, 't Hoge Huis te Muiden: Teksten uit de Muiderkring (Utrecht: Het Spectrum, 1972); De gedichten van Tesselschade Roemers, ed. by A. Agnes Sneller and Olga van Marion (Hilversum: Verloren, 1994). On the Muiderkring, see Karel Porteman and Mieke B. Smits-Veldt, Een nieuw vaderland voor de muzen (Amsterdam: Bert Bakker, 2008), p. 354; Leendert Strengholt, 'Over de Muiderkring', in Cultuurgeschiedenis in de Nederlanden van de renaissance naar de romantiek: Liber amicorum J. Andriessen S.J., A. Keersmakers, P. Lenders S.J. (Leuven: Acco, 1986), pp. 265-77, http://www.dbnl.org/tekst/ streoo6muido1_01/streoo6muido1_01_0oo1.php.

3 See Nina Geerdink, Dichters en verdiensten: De sociale verankering van het dichterschap van Jan Vos (1610-1667) (Hilversum: Verloren, 2012). 
The full extent of the Dutch poetic sphere and its relationship to the republic's public sphere is made clear in the voluminous work of Joachim Oudaen (or Oudaan, 1628-1692), Mennonite, Collegiant, Leiden-educated tile maker from Rotterdam, sometime resident of Rijnsburg. ${ }^{4}$ Collegiantism grew up after the 1619 Synod of Dordt outlawed the Remonstrants and exiled their leaders; Collegiant churches were open, clergy-free associations, mostly and at first of Arminians and Mennonites; at monthly meetings all present had the same liberty to interpret the Bible, that is to prophesy, and to pray: 5 'Collegiantism was intended, paradoxically, to give concrete form to a "non-church," an "invisible church" of all "unpartisan" believers, one that brought believers together without binding them or passing judgment. ${ }^{6}$ Would we expect a Mennonite and Collegiant to produce a treatise on the observations about Roman power structures that might be derived from Roman coins? ${ }^{7}$ Just the poetry of Oudaen that engages with painting is enough of an oeuvre to be seriously absorbing to scholars for a considerable time. ${ }^{8}$ Once again we are reminded of the cultural richness of Dutch radical religion: it was not a world of sola scriptura (as was so often the case in England), although city dwellers like Oudaen were more inured to this richness than were rural but still literate Mennonites. ${ }^{9}$

Oudaen's second birthday poem for the cloth merchant, engraver, and playwright Willem van Heemskerk (1613-1692) begins as a dream vision in which the dreamer poet cannot initially see his subject. 'Poetry arrives as the solution to this lack of sight, and is likened to painting, conceived as feminine with a reference Arachne, the weaver turned by Minerva into a spider, as recorded in

4 See Johannes Melles, Joachim Oudaan: Heraut der verdraagzaamheid: 1628-1692 (Utrecht: Kemink \& Zoon, 1958).

5 See J.C. van Slee, De Rijnsburger Collegianten: Geschiedkundig onderzoek: Met een inleiding van S.B.J. Zilverberg (Haarlem: Bohn, 1895; repr. Utrecht: HES, 1980); and Andrew C. Fix, Prophecy and Reason: The Dutch Collegiants in the Early Enlightenment (Princeton: Princeton University Press, 1991).

6 Gerrit Voogt, “Anyone Who Can Read May be a Preacher”: Sixteenth-Century Roots of the Collegiants', Nederlands Archief voor Kerkgeschiedenis, 85 (2005), p. 409.

7 Joachim Oudaen, Roomsche mogentheyt, of Naeuwkeurige beschryving, van de macht en heerschappy der oude roomsche keyseren, 1st edn (Amsterdam, 1669).

8 See Amy Golahny, Rembrandt's Reading: The Artist's Bookshelf of Ancient Poetry and History (Amsterdam: Amsterdam University Press, 2003).

9 The case for urban-rural differentiation is made by Ben Kaplan, Divided by Faith: Religious Conflict and the Practice of Toleration in Early Modern Europe (Cambridge: Harvard University Press, 2007). 
Book VI of Ovid's Metamorphoses, we might legitimately be surprised to find her in Oudaen's verse. ${ }^{10}$ For Oudaen was strongly against the presence of classical elements in poetry: he felt they introduced confusion since they were not clearly understood - at best they were matters for interpretation and, far worse, the presence of pagan deities was a dishonour to God. Oudaen had no place for them in his utterly reformed verse, and he is most known today, as noted above, for his hymns. This led to his famous attack (despite his admiration for the poem) on the use of classical mythology in Johannes Antonides van der Goes's Ystroom of 1671, to which van der Goes (who was, like Oudaen, from a Mennonite family) replied.1 Devoid of mythology and all ornament, Oudaen's verse was an assault on the very idea of poetry as it had previously existed. In accordance with the ideas of the Collegiants, he stated that natural reason instead was the best servant of gospel truth. Low on imagery, his poetry is recognisable only by its rhymes and rhythms; it is profoundly discursive and has not won admirers, although his rhymed psalms were widely adopted in Mennonite worship, at first in Rotterdam and then, up to the nineteenth century, more broadly in the Netherlands. The only way to be godly, Oudaen says, is to undertake the purge that leads to full reformation. Oudaen follows the literal biblical epic pattern established by the greatest Dutch poet and dramatist of the period - and, from 1641, the Roman Catholic - Joost van den Vondel, in Johannes de Boetgezant (1662), but this pattern is interrupted in Oudaen's poetry by 'comparisons, spiritual interpretations, admonitions, and exclamations' that might more readily be associated with the Anabaptists. ${ }^{12}$ There is no doubt about Oudaen's confidence in the republic's civic achievement, as is exemplified by the poem he wrote to accompany one of his friend's- the painter Samuel van Hoogstraten's - self-portraits, where an outstanding rationality is seen to be evident in the painting itself. ${ }^{13}$

One target of Oudaen's ire with respect to the ancients in contemporary verse was Andries Pels (1631-1681), the classicising poet who was a driving force in the theatre reform group Nil Volentibus Arduum and the author of

10 Oudaen, 'Ter verjaringe van den heere Willem van Heemskirk' in Joachim Oudaen, Gedichten, ed. H.K. Poot (Delft: Reinier Boitet, 1724), 169-70. See Marijke Spies, Rhetoric, Rhetoricians and Poets: Studies in Renaissance Poetry and Poetics (Amsterdam: Amsterdam University Press, 1999), pp. 103-05.

11 'Boekenlof. Op den Y-strom van J. Antonides', in Joachim Oudaen, Poëzy verdeeld in drie deelen, ed. by David Van Hoogstraten, 3 vols (1712), II, p. 33 .

12 See Spies, Rhetoric, Rhetoricians and the Poets, p. 105.

13 See Celeste Brusati, Artifice and Illusion: The Art and Writing of Samuel Van Hoogstraten (Chicago: University of Chicago Press, 1995), p. 137. 
the attack on the histrionic (and allegedly immoral) tradition in Dutch drama, Gebruik én misbruik des tooneels (The Use and Abuse of Drama, 1681). ${ }^{14}$ Pels invited Oudaen to comment on his verse; the comments, dated 13 September 1681, were not published until 1713 and in them Oudaen accused Pels of being arbitrary in his prosodic stresses, and the result-Oudaen claimed-was an obscurity of style that rendered the verse incomprehensible: 'so that [he went] towards some trashy ruin, by such trite instruction, with his examples and regulations for the measure of the epic, desiring containment or channelling' ('zoodat het tot eenige voddery vervalt, alle dusdanig onderwys, mey zyne voorbeelden en regelen, in de maat van het Heldendicht te willen insluiten of bevarten'). ${ }^{15}$ Oudaen's main objection is that the art of poetry is presented by Pels as a universally unbending statute on rhyme that acts as an infallible guide for the poet and his artistic creation. ${ }^{16}$ Oudaen maintains that servility must follow from this reliance on strict metrical form, questions whether such literary law-abiding actually occurred in antiquity (or at any point thereafter), and insists that freedom is the only way forward for the poet. So many impediments deliver artistic death; rules exist to be violated. Oudaen makes a clear equation, too, between metrical and political freedom, and against the argument for the imitation of ancient Latin verse: 'in deze Dichtkunst ingeworpen, en die voornamelyk onze Vaderlantsche taal, vryheit, gewoonte; en wel herkomen gebruík betreft' ('deeply rooted in this poetic art, and the principal [aspect] of our native language, freedom, custom; is well fitted to its use') ${ }^{17}$ Oudaen and Van der Goes were united in their resistance to French literature and culture: they saw it as a threatening hegemonic imperialism. A generation later their writings would be seen as crucial in an attempt to stem what was seen as Dutch decline in every sphere in the face of French pre-eminence. ${ }^{18}$

14 Modern edition in Andries Pels, Gebruikén misbruik des tooneels, ed. by M.A. Schenkeveldvan der Dussen (Culemborg: Tjeenk Willink-Noorduijn, 1978).

15 Joachim Oudaen, J. Oudaan's Aanmerkingen over Q. Horatius Flaccus dichtkunst, op onze tyden en zeden gepast, door A. Pels (1713), p. 30 . Modern edition in Andries Pels, Q. Horatius Flaccus dichtkunst op onze tijden en zeden gepast, ed. M.A. Schenkeveld-van der Dussen (Assen: Van Gorcum \& Comp. B.V., 1973), also on the DBNL site: http://dbnl.org/tekst/ pelsoo1qhoro1_01/. Rembrandt himself had produced some engravings for the printed edition of Vos's play.

16 Oudaen, J. Oudaan's Aanmerkinge, p. 32.

17 Ibid.

18 See Wijnand W. Mijnhardt, 'Dutch Culture in the Age of William and Mary: Cosmopolitan or Provincial', in The World of William and Mary:Anglo-Dutch Perspectives on the Revolution of $1688-89$, ed. by Dale Hoak and Mordechai Feingold (Stanford: Stanford University Press, 1996), pp. 219-33. 
Oudaen believed that Pels did not practice what he preached in his dramas, that his respect for strict rhyme schemes was too constraining, and that he was thus betraying the Dutch language. Oudaen and Pels were also caught up in a debate on the nature of drama. Pels's desire to purify the theatre was anathema to Oudaen, who believed that the histrionics and violence of the tragic tradition he followed had a valid function that could be traced back to Jan Vos's Aran en Titus of 1641 (a play that had its sources in Shakespeare's Titus Andronicus and in a German play of 1620 , and that is notable for its use of speaking ghosts and talking severed heads), one of the earliest plays to be performed at the Amsterdam Schouwburg after it opened in $1638 . .^{19}$ The cultural figures line up in an interesting and significant way in this debate: Pels accused Vos of writing like Rembrandt painted, following nature rather than precept and thus producing pictures of servant girls or burger's wives rather than ideal and inspiring mythological subjects:

\section{Slappe borsten,}

Verwrongen' handen, ja de neepen van de worsten

Des ryglyfs in de buik, des kousebands om 't been,

't Moest al gevólgd zyn, óf natuur was niet te vréên;

Ten minsten zyne, die geen régels, nóch geen réden

Van évenmaatigheid gedoogde in 's ménschen léden. (ll. 1109-14)

\section{Weak breasts in need of bracing}

Gnarled hands, e'en stomach weals caused by tight bodice lacing

And legs with pressure marks from garters, just released,

It must be followed all, or nature is not pleased.

That is: his nature isn't: rules are no more acknowledged

And for all human limbs, proportion is abolished. ${ }^{20}$

19 The standard edition is Jan Vos, Toneelwerken: Aran en Titus, Oene, Medea, ed. by W.J.C. Buitendijk (Assen: Van Gorcum, 1975). See also Helmer Helmers, 'The Politics of Mobility: Shakespeare's Titus Andronicus, Jan Vos's Aran and Titus and the Poetics of Empire', in Politics and Aesthetics in European Baroque Tragedy, ed. by Jan Bloemendal and Nigel Smith (Leiden: Brill, 2016), pp. 344-72.

20 Andries Pels, Gebruik én misbruik des tooneels, ed. by M.A. Schenkeveld-van der Dussen; translation by August F. Harms in Literary History of the Low Countries, ed. by Theo Hermans (Rochester: Camden House, 2009), p. 225. Pels would have found support for his views in the introduction to Giovanni Pietro Bellori's Vite de'Pittori, Scultori et Architetti Moderni (Rome, 1672). For Rembrandt and the drama, see Eric Jan Sluijter, 'Rembrandt's Portrayal of the Passions and Vondel's "staetveranderinge", Netherlands Yearbook for History of Art / Nederlands Kunsthistorisch Jaarboek, 60 (2010), pp. 285-306. 
Pels, in contrast, wanted to import the 'pacified' Parisian drama of Corneille and Racine, and encouraged the dissemination of Spinoza's philosophy. ${ }^{21}$

Oudaen's insistence on freedom should not be taken lightly. Pels thought that the stage was a subversive force, damaging to the polity: he agreed that the theatre should have been closed, as it was between 1672 and 1677. But Oudaen regarded the stage as part and parcel of Dutch 'vryheid' or freedom. Haagsche broeder-moord, of dolle blydschap (Fratricide at The Hague, or Mad Joy, 1673), Oudaen's play about the killing and dismembering of the de Witt brothers, was never performed and was probably not published until 1712, during the second stadholder-less period; on his deathbed in 1696, he asked that it be burned. Oudaen was not wholly against princely authority: he said that he would have been partial to monarchy had he lived in England, and he had attacked Oliver Cromwell as a usurping tyrant in Konradyn (1649). ${ }^{22}$ Indeed, later on and in contrast, Oudaen saw Willem III continuing the line of Johan de Witt by upholding toleration in the terms of the Glorious Revolution of 1688 . But back in 1673 this possibility was still in the future. In a poem entitled De vryheid. Op den troon gevestigt (Freedom Established on its Throne) and written shortly after the edict of 5 August 1667 that abolished the office of stadholder in perpetuity, Oudaen had compared the four stadholders Willem I (1533-1584), Maurits (1567-1625), Frederick-Hendrik (1584-1647), and Willem II (1626-1650) to, respectively, Julius Caesar, Augustus, Tiberius, and Caligula: an increasingly unpleasant, debased, and tyrannical trajectory. ${ }^{23}$

The fact that publication dates are missing from early title pages of the play should be of concern to any book historian. So should the place of publica-

21 The career of Nil Volentibus Arduum and Pels's reform is traced in Francesco Sbarra et al., Tieranny van eigenbaat (1679): Toneel als wapen tegen Oranje, ed. by Tanja Holzhey et al. (Zoeterwoude: Astraea, 2008); Andries Pels, Didoos doot: Treurspel. Met eenige konstwercken, vertoont op d'Amsterdamse Schouburg (Amsterdam, 1684); Roberto Bordoli, Etica arte scienza tra Descartes e Spinoza: Lodewijk Meyer (1629-1681) e l'associazione Nil Volentibus Arduum (Milan: F. Angeli, 2001). Meyer is a far more likely figure than Pels to have been disseminating Spinoza.

22 David van Hoogstraten, 'J. Oudaens leven', in Oudaen, Poëzy, p. 21; Joachim Oudaen, Haagsche Broeder Moord, Of Dolle Blydschap: Treurspel, ingel. en voorz. van annotatie door een Werkgroep van Utrechtse neerlandici (Utrecht: Tweede Druk, Instituut De Vooys, 1984), p. 39 .

23 Joachim Oudaen, De vrijheid op den troon gevestigt (Rotterdam, 1668). 
tion, Fredrikstad: a settlement established by Remonstrant exiles in Holstein. This suggests a false imprimatur. Haagsche Broeder-Moord's assertion of an Orangist conspiracy is so strong it is hard to imagine that Oudaen would not have been arrested at the time had it been printed and distributed in the $1670 \mathrm{~s}$ and $168 \mathrm{os}$. The degree to which the play might have circulated in manuscript is not known, although it is not thought to have been performed.

The events of 20 August 1672 that are recorded in the play were witnessed by Oudaen, who had travelled from Rotterdam to The Hague that day; he later recorded what he saw in a handwritten recollection. ${ }^{24}$ It was the rampjaar, the terrible year in which the United Provinces was brought to its knees by English naval action during the Third Anglo-Dutch War. ${ }^{25}$ The account of the play's contents that follows is largely descriptive; there is very little criticism of it in the secondary literature. ${ }^{26}$ The drama begins with two House of Orange cousins, Odyk and Zuylestein, conspiring in the name of Willem, although Zuylestein fears that the De Witts will escape, a reflection of their skilful statecraft. ${ }^{27}$ Two preachers, Simonides and Landman, ${ }^{28}$ learn that rousing sermons could raise a crowd against Johan de Witt and give the conspiracy moral justification, while enhancing the reputation and resources of their church. There is a reference to personal experience here: Oudaen was well aware of the precariousness of his own position as well as that of the De Witt brothers and other republicans in 1672 , in the face of persistent pamphlet campaigns and

24 Gemeentelijk Archief Rotterdam, Hs. Verz 1575, 1672: Joachim Oudaen, 'Dagverhaal van de meuijterije van Rotterdam des jars 1672 door J. Oudaan Janszoon'.

25 See Michel Reinders, Gedrukte chaos: Populisme en moord in het Rampjaar 1672 (Amsterdam: Uitgeverij Balans, 2010), translated as Printed Pandemonium: Popular Print and Politics in the Netherlands, 1650-72 (Leiden: Brill, 2013). The lynching of the De Witt brothers continues to raise shocked interest, even internationally and in the popular press: see Dan Fawkes, 'PM Eaten by the Mob', Daily Mail, 14 July, 2011, p. 55.

26 The exceptions are the 1984 edition of Haagsche Broeder Moord, which is richly annotated but very difficult to obtain (see note 22); Lia van Gemert, 'De Haagsche Broeder-Moord: Oranje ontmaskerd', Literatuur, 1 (1984), pp. 268-76; Bettina Noak, Politische Auffassungen im niederländischen Drama des 17. Jahrhunderts (Munich: Waxmann Münster, 2002), pp. $262-80$. However, the text of the play and some other materials can be read on the Netherlands Library of Dutch Literature website: http://www.dbnl.org/titels/titel. php?id=oudaoorhaago1.

27 Willem Adriaan van Nassau, heer van Odijk (c. 1632-1705), the son of Louis van Nassau (1602-1665), himself the illegitimate son of Maurits, Prince of Orange; Frederick Nassau de Zuylestein (1608-1672), an illegitimate son of Frederick Henry, Prince of Orange, governor of the household of William III from 1659 until his dismissal in 1666.

28 Simon Simonides (1629-1675); Thaddeus Landman (1621-1681). 
preaching from Calvinist divines. ${ }^{29}$ Zuylestein and Odyk urge the preachers on, since the Orange brothers fear that the De Witt brothers will be protected by the cavalry and that the force of righteous (as they see it) popular violence would thus be compromised. The act ends with the citizens afraid that state conflict and the predicament in which affairs had been left by the De Witts would drag the entire republic down.

The second act begins with Johan hoping that his elder brother Cornelis would be acquitted and would leave the Gevangenpoort prison, where he had been held on a treason charge for conspiring to end the life of the Prince of Orange on the allegation of Willem Tichelaar. We meet Johan's sister and his daughter Anna (Anna de Witt, 1655-1725), and Johan places his life in the hands of God, knowing the desperate state of affairs. Still, he does not believe his or his brother's life is ultimately in danger. His father Jacob, fearing a conspiracy, advises Johan not to visit the prison to help Cornelis. This is one of several inferences of an Orangist conspiracy to murder the De Witts of which Oudaen appears, at least in writing, to be the origin..$^{30}$ The play draws a comparison between the tyrannical actions of the Spanish Duke of Alva (1507-1582), Maurits, and Willem III (1650-1702) against their pensionaries Van den Ende, Oldenbarnevelt, and De Witt. Alva is portrayed as acting within the bounds of law, Maurits goes beyond him in committing a judicial murder, while Willem III is the most bloodthirsty and does not regard himself as under the law. As matters stood in the state, Johan had actually resigned on 4 August and Willem had resumed his role in government. Yet, as the play reveals, this was not enough.

The third act begins with further discussion among the citizens about the risks presented by the De Witts and about which brother is more to blame. The crowd is further incited by Willem Tichelaar (in Oudaen's view, the perjured witness against Cornelis), who reports to them on the hearing. Cornelis is not condemned to death by the Court of Holland but banished, and this incenses the crowd, whose members believe the sentence to be too light. (Later we will learn that Tichelaar has held undue sway over the judges.) Cornelis and Johan meet briefly, but unfortunately the preachers continue to incite the crowd and the brothers' coach driver is sent away. A little comic relief is provided: the crowd asks the coachman if the 'De Witt dog' is in the coach, and he replies in the affirmative, meaning, however, that he is carrying the family dog-not

\footnotetext{
29 See Jill Stern, Orangism in the Dutch Republic in Word and Image, 1650-75 (Manchester: Manchester University Press, 2010).

$30 \quad$ Reinders, Printed Pandemonium, p. 162.
} 
Johan de Witt. The chorus concludes by noting the comparable hypocrisy of Roman Catholics and Calvinists.

In the fourth act, a further standoff with the crowd makes Johan realise that they are lost. (In actuality, the civic militia was acting with the crowd, and cavalry that had been sent to keep the peace was redeployed to guard the city gates: the de Witt brothers at that point were completely defenceless, and were in fact eventually taken out of the prison by a group of citizens.) In a further confrontation with the burghers during which Johan tries to justify himself, the brothers are shot. The prologue to the fifth act expresses surprise and contempt that this has happened given that Cornelis had been so important to the Dutch navy and Johan had been such an impressive statesman. ${ }^{31}$

In the fifth act, grieving is left to Jacob, his daughter, and Anna de Witt; the story of the brutal dismemberment of the brothers is told by the chorus to Johan's family, and the remains of the de Witt brothers are brought to Johan's house. We are told that the sight of the corpses will lead to Jacob's insanity: at first he cannot recognise them, but then the awful truth dawns upon him. The chorus bewails the removal of the De Witt family from politics and compares the Prince of Orange to Charles IX of France after the St. Bartholomew's Day Massacre, the mass killing of French Protestants in Paris on 24 August, 1572, in which the king was complicit, and after which he exploited the disarray of the Protestants, or Huguenots. That, of course, was neither a happy memory nor prognostication..$^{32}$ We should note the engravings that accompanied printed editions of the play and the powerful painting by Jan de Baen of the dead brothers suspended upside down, flayed and disembowelled, like butchered animals.

See Herbert Harvey Rowen, John de Witt, Grand Pensionary of Holland, 1625-1672 (Princeton: Princeton University Press, 1978); Herbert Harvey Rowen, John de Witt, Statesman of the 'True Freedom' (Cambridge: Cambridge University Press, 1986); Luc Panhuysen, De Ware Vrijheid: De Levens van Joan en Cornelis de Witt (Amsterdam: Atlas, 2005).

32 See Arlette Jouanna, The Saint Bartholomew's Day Massacre: The Mysteries of a Crime of State (24 August 1572) (Manchester: Manchester University Press, 2013). 


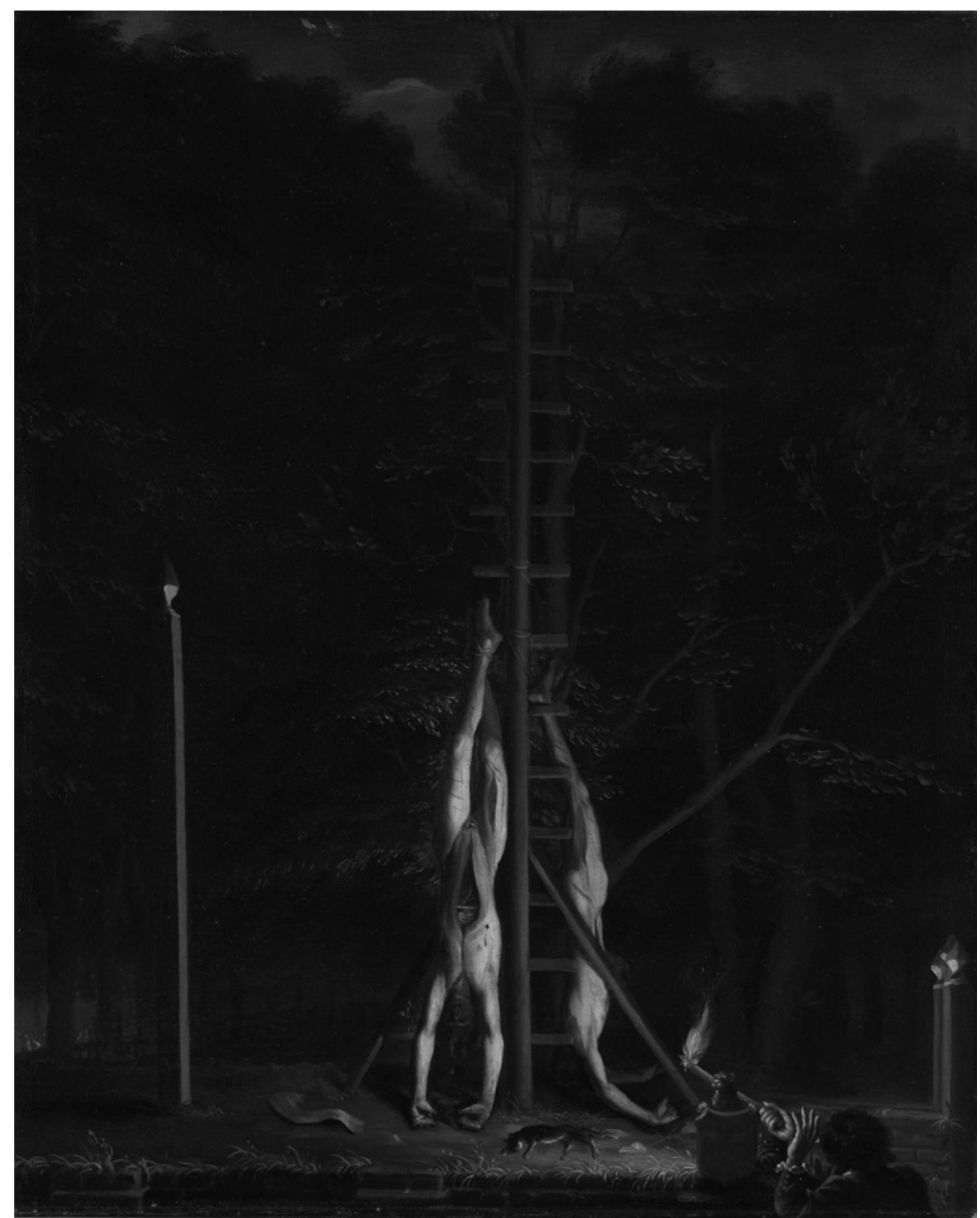

FIGURE 6 'The Corpses of the de Witt Brothers, Jan and Cornelis, Hanging on the Groene Zoodje on the Vijverberg, The Hague, 1672', attr. Jan de Baen, 1672-c. 1675, Rijksmuseum, Amsterdam, Netherlands. 
At one point in the play, a contrast is made between this dismal scene and the heroic portraiture previously made of both Cornelis and Johan. ${ }^{33}$ Yet it is also true, argues the chorus, that the republic will pay a heavy price-even to the extent of its own destruction-for it will now be lacking the various skills of the De Witt brothers from which it had so profited in the past; and now, too, Willem will have their miserable deaths on his conscience.

As a printed publication, not a performed drama, the play's appearance might initially make one think that it took its place among the many publications that played a role in the formation of public opinion during and after the rampjaar. Yet the majority of published pamphlets at this time in fact supported the case for the removal of the De Witts, and the argument has been made that the press had a real impact on motivating the ritual murder and dismemberment of the brothers. Traditionally, historiography has agreed with Oudaen's account in many respects, but more recent views offer different perspectives. It is now argued that Cornelis De Witt may indeed have been involved in plotting against Willem and that, despite his dubious reputation, Tichelaar may not have been an untrustworthy villain. ${ }^{34}$ The instruments of state investigation and punishment employed tactics of a physical severity very similar to the violent end of the De Witts. By one account, Cornelis was tortured in the Gevangenpoort by having his shins broken and by having heavy weights suspended from his toes so that circulation of blood in his legs stopped. (In any case, he was suffering from extreme gout.) If this instance of torture was true, he would have found it extremely difficult, if not impossible, to leave the prison by walking - even allowing for his recovery time. Johan himself was still recovering from a previous assassination attempt by Jacob van de Graaf. Whatever the truth of these historical circumstances, Oudaen's civic martyr drama was responding to a situation in which an identifiable group of prominent citizens (apparently led by Hendrik Verhoeff, $1645^{-1710}$, silversmith and militia captain) and not a mindless mob killed the brothers with their own hands and weapons, dismembered them, and cooked and ate their body parts (fingers, hands, ears, noses, feet, genitals, hearts, lungs) in a ritual purging of what they regarded as a tainted body politic. This is now understood by some historians to have been a rationally driven instance of early modern retributive symbolic justice, not the irrational actions of a crazed mob: as the perpetrators saw it, the further punishment of

See Oudaen, Haagsche Broeder-Moord (Utrecht: Tweede Druk, Instituut de Vooys, 1984), pp. 34-35, 145; Frans Grijzenhout, 'Between Memory and Amnesia: The Posthumous Portraits of Cornelis and Johan de Witt', JHNA, 7 (2015), p. 5.

On this latter point, see Reinders, Printed Pandemonium, p. 151. 
dismemberment after execution was fitting to the crime. That retribution was, at the time, the source of very detailed pamphlet commentary. Surviving bits and pieces of the De Witts would change hands for handsome sums of money; even their supporters kept some of these relics and other personal effects as tokens of the republican tradition. We lessen the significance of the play and of Oudaen's intentions unless we take these factors into account. Indeed, the title page's unidentified quotation from Virgil, a chronogram making 1672 , is quite appropriate: 'PraeCLaro gaVDent perpVsI sangVIne fratrVM' ('Joyfully they smear themselves with the blood of the illustrious brothers', Georgics II. 510). Thus Oudaen gave the lynching of the De Witts classical importance.

Oudaen was putting forward one particular viewpoint; other publications reveal a complicated set of different opinions. Johan de Witt's published writing was itself too learned and technical to connect with the reading public. The contrary was true for Orangist (or at least anti-De Witt) publications, in which the republicans were depicted as self-interested men who were prepared to place private gain over the public good and national security. A significant body of pamphlets enacted the death sentence in print weeks before it happened; some argued that execution and martyrdom were justified, even invoking comparisons with John the Baptist. Even those who did not approve of lynching because they objected to mob violence and to people taking justice into their own hands thought the killing was justified. Oudaen, therefore, was not just engaging in the defence of a political viewpoint, however much his careful attention to historical detail in the play might suggest this. He was also exploiting the aesthetic potential of the drama and using it to counteract the bloodthirstiness-however rationalised and justified - in political culture at this point in the rampjaar crisis. This extends to his attempt to capture, in dramatic form, the street-side discussions among citizens, such as the exchange of different viewpoints pro et contra the De Witts that occur at the beginning of act III. These passages certainly carry energy and are reminiscent of Ben Jonson's renderings of urban life. Indeed, in a severe critique of the play's quality, Lia van Gemert regards this section as the only performable part of the text. ${ }^{35}$ Beernaart is a rude and illmannered character whose passions drive his opinions and who wishes to make short work of the De Witts. There is more than a hint of Seneca in the text:

\section{Beernaart.}

De moedwil acht geen stuk te stout,

In 't geenze durft ter handen slaan:

35 Van Gemert, 'De Haagsche Broeder-Moord', p. 273. For a much later dramatic rendering of these events in German, see Ferdinand von Saar, Die beiden de Witt: Trauerspiel in fünf Acten (Heidelberg: G. Weiss, 1879). 
Arent.

En d'onversaagtheid zal bestaan,

Uit nood, het geen waar door ze niet,

Of zeer bezwaarlyk, heene ziet:

Want een benarde kat in 't nauw

Waagt sprong, op sprong, en zet den klauw

In 't geen waar aan geen vatten was,

Of vliegt al dryvend door een glas.

\section{Beernaart.}

De Vogel, hier in 't tralinet

En yz're kevi vast gezet,

Is onversaagt, en stout, en schalk,

En afgerecht gelyk een Valk,

Of Arent, die met klauw, en bek,

Een' mind'ren vogel breekt den nek;

Of die geraakt aan ruime lucht,

Noit achterhaalt word in zyn vlucht. ${ }^{36}$

Beernaart.

Malevolence considers no venture too daring in what it dares to do.

Arent. [Eagle]

And intrepidity will dare - out of need - that of which it cannot, or hardly, see the

consequences, for a dire cat cornered takes the plunge again and again and puts its claws

into that which is slippery or runs very quickly through a glass.

\section{Beernaart}

The bird [i.e., Cornelis de Witt], here imprisoned behind iron bars and the iron cage,

is intrepid, and daring and cunning, and trained like a falcon or an eagle which with its

claw and beak breaks the neck of a smaller bird, or which if it is in the open air is never caught in its flight. ${ }^{37}$

37 My thanks to Jan Bloemendal for his translation of these passages. 
By contrast, Ernst and Frank speak for the De Witts and so represent rational detachment, objectivity, and honesty:

\section{Ernst. Frank.}

Ja zeker! gaat het zoo! en meent men, zonder spreken,

Ons dit voor gladde munt dus in de hand te steken:

Daar zeg ik neen toe; ' $k$ ben veel liever ver van daan,

Dan over, of omtrent, een werk dat zoo zal gaan.

\section{Frank.}

Zoo komje, zonder 't slot te hooren, weer na buiten?

Of zonder datje weet wat hier den Raad zal sluiten?

Dat 's wonder!

\section{Ernst.}

't Lust me niet te morssen in een werk,

Daar 't schaamteloos bedrog gekent aan merk, op merk,

Met baar geweld die rol van boosheid zal volspelen;

' $\mathrm{k}$ Zoek in den lof, of ' $\mathrm{t}$ loon, niet garen diep te deelen;

En al die eerlyk is, of deugdzaam van gemoed,

Verwaarloost deugd en eer indien hy anders doet.

O Rechters! zelve Gy, die met het werk verlegen

Dit moog'lyk tegensprakt, als wien het onrecht tegen

De borst was, nu gy niet dorst spreken uit de borst,

Zoo rustig als 't betaamde, al mê met bloed bemorst,

Zult in der eeuwigheid dien naamsmet noch zien kleven

Op u, en uw' geslacht, uw' kind'ren, en uw' neven;

Uw' schaduw zal u zelf doen sidd'ren, waar gy zyt,

En 't knagend' naberouw u nagaan met verwyt:

Maar om die waarheid niet met bitt'ren hoon te ontgelden,

Indien w' hier onderling een woord in vryheid melden,

Zoe treed wat aan d'een zy; of wandel wat omher,

Zoo kan m' op ons bedryf niet letten, als van ver.

\section{Frank.}

k Verlang hoe Tichelaar zyn zeggen heeft bewezen.

\section{Ernst.}

De valsheid van dien schelm is uyt zyn mond te lezen;

Want hoe hy 't stuk beglimt, en oppronkt 't geen hy zeit 
Met een verhaal, het welk met groote omzichtigheid Hem voorgeschreven schynt; zy kykt 'er dwers door henen:

En zoo men van ter zyd' zyn zeggen poogt t' ontzenen, Waar door de valsheid best zouw komen aan den dag, Men schreeuwt 'er tegen aan, zoo vinnig als men mag. ${ }^{38}$

\section{Ernst. Frank.}

Yes, sure, thus it goes, and people think, without saying it, to put this as slippery coins in our hands. I say no to this; I prefer to be far from a job, than to be engaged in it.

\section{Frank.}

Thus you come out again without hearing the end? Or without knowing what the Council will decide? That is strange!

\section{Ernst.}

I do not want to act dishonestly in a deed in which shameless deception that is recognised in several ways with pure violence will accomplish that evil task. I do not gladly share in praise or reward. And everyone who is honest or has a virtuous mind will disregard virtue and honour if he acts in a different way. O Judges! Even You who, having troubles with this matter, possibly refuted this, since you disapproved of this injustice and dare not to speak honestly as openly as you should have done, you also messed with blood, you will see this blemished name stick in eternity to you, your race, your children and grandchildren. Your very shadow will make you tremble wherever you are, and gnawing remorse will follow after you reproachfully. But to prevent the truth being expressed with bitter scorn if we speak together a word in freedom step aside, or stroll somewhat, so that people can't see what we are doing but from afar.

Frank.

I would like to know how Tichelaar has proved what he has said.

\section{Ernst.}

The falsity of that rascal can be read from his mouth; for however he perverts the venture and embellishes his words with a story, something which he seems to be required to do with great caution, [the truth] shines right through it, and if one wants to disprove his words from the side 
lines, whereby the falsity would best come to light, one cries out against it as strongly as possible.

Oudaen attempts to maintain the classical unities and, to that extent, shares Vondel's debt to the classical tradition and to the work of the Dutch classical scholars, notably Heinsius and Vossius. There is an even distribution of action across the whole play and closure for each act. The combination of prolepsis and retrospection not only unifies the action in an arc from the beginning of the first act to the end of the fourth, but also gives the play a structure for reflection by the discerning imagined audience member or actual reader. Nonetheless, the extended argument from principle and Oudaen's sense that he should be faithful to the events he witnessed puts considerable pressure on the tragic form. The text is half as long again as the typical Dutch play text of this period (some three thousand rather than two thousand lines). As an example of this expansiveness, here the De Witt brothers discuss their situation at length while pondering the situation of the republic:

Kornelis de Witt. Johan de Witt.

Kornelis.

O Broeder, Vryheids stut, en rechterhand der Vromen, Naast God 's Lands toeverlaat, waar is het toe gekomen!

Hoe word uw' zorg, en trouw, en arbeid, dag en nacht, Uw' wysheid, en beleid, verwaarloost en veracht! Hoe word die dierb're schat van uw' vermoge gaven, Vertreden met den voet, en in het stof begraven! Onmensch'lyk Hof, in dienst van uwen dwingeland Verslaaft, was 't niet genoeg, dat gy me rekt, en spant, En pynigt? daar gy zelf gepynigt in ' $t$ geweten, Uw' eer, uw' eed, uw' God, en Godsdienst hebt vergeten? Moest gy myn Broeder noch bedraayen in dien ramp! Waar van 't bewimp'len zal verdwynen als een damp: Op dat het helsch geweld hem dinge naar zyn leven: Dat zal in eeuwigheid de Staat u niet vergeven; Nadien het Vaderland hier met een hart-quetsuur Geraakt word, die 't gevoelt zoo lang het leven duur? Tot dat het magteloos zieltoogende uit zal quynen; Vermits het met een zucht de Vryheid ziet verdwynen.

\section{Johan.}

Myn waardste, neem geduld: Staat, Vryheid, Vaderland, Is maar een yd'le klank van namen, zonder stand, 
Of grondsteun; en verstrekt een speeltuig voor de winden

Van 't wispelturig volk; gelyk we nu bevinden:

Want zyt gy, dapp 're Man, gepynigt en gerekt,

Mishandelt van een' beul! dat toont ons, dat ontdekt

Hoe haast d' ondank baarheid de weldaat heeft vergeeten;

En dat geen Vaderland de vroomheid af kan meten,

Waar door het, met het loof van uwe lauwerkrans

Beschaduwt, zyn gezag tot onverwelkb'ren glans

Scheen op te beuren, en onwankelbaar te vesten:

En ach! bewyst men zulk een snoodheid aan de besten!

Aan eenen die noch niet ontslagen van 't Gezag

Van Opperoverste der Zeemacht, niet en mag

Van iemant ooit gehoont, veel min beledigt worden;

Ten zy met quetsing van's Lands Oppermacht, en orden,

Welks eere op hem berust; die, na gedaan bescheid,

Zyns machts, in handen van zyn' Meesters afgeleit,

Dan eerst ontslagen word; 't en zyze 't zelf belasten:

$\mathrm{Nu}$ dan het Hof in u 's Lands Hoogheid aan durft tasten,

En schenden, wien gelust dan Vaderland, of Staat,

Of voorstand van 't Gemeen, zyn vroomheid, of zyn raad

Op t"off'ren? ${ }^{39}$

\section{Cornelis de Witt. Johan de Witt.}

Cornelis.

O brother, Freedom's support and right hand of the righteous, with God the Country's mainstay, what has it come to! How your care and faith, your labour both day and night, your wisdom and policies are neglected and despised! How that precious treasure of your great gifts [is] trampled and buried in the dust! Inhuman Court [i.e., of William III], made a slave in service of your tyrant, wasn't it enough to stretch me, draw me, and torture me? Whereas you yourself, tortured in your conscience, have forgotten your honour, your oath, your God, and your Religion? Should you involve my brother in that disaster, the scrambling of which will disappear as a vapour, since the hellish violence will try to kill him: The State will never forgive you that, since the Country is struck a deathblow that it will feel as long as life will last, until it waste away, powerless and moribund, since it experiences Freedom disappearing with its last sigh. 


\section{Johan.}

My dear, have some patience: State, Freedom, Country, are merely idle sounds of names, without foundation or solidity, and give full play to the winds of the fickle people, as we experience now. For you, brave man, are tormented and stretched, tortured by a headsman! This shows us, this reveals how quickly ingratitude has forgotten benefaction, and that no country can value the bravery by which, shaded by the leaves of your wreath, it seemed to elevate its authority to an unfading lustre and give it an unshakable foundation. Alas! Such a wickedness is done to worthies! To someone who, not yet dismissed from the office of the Supreme Commander of the Navy, is not allowed ever to be scorned by anyone, and even less is allowed to be offended. But if it is done, then the States General and the laws are violated, whose honour rests on the man who, after having given account of his power, is carried away in the hands of his masters and then is relieved of his duties, unless they have serious criticism of it themselves. Now [that] the court dares to affect and infringe the majesty of the Republic in you, who will wish to sacrifice for his country or state, or his bravery or prudence for the promotion of the common interest?

There is copious reference in the dialogue to the involvement of England in Dutch affairs. Charles II persistently and in different ways backed the interests of his nephew Willem. Cornelis de Witt had been present at the Dutch navy's successful raid on the English navy in the River Medway in July 1667, and was widely celebrated for his countrymen's victory. This was the action that brought the Second Anglo-Dutch War to a successful conclusion on Dutch terms. In the previous decade, Johan de Witt had made peace with the Cromwellian Protectorate with the inclusion of the infamous secret clause stating that the stadholder be excluded from politics, and this is indeed what happened, culminating in the exclusionary edict of 5 August 1667. Oudaen depicted republican outrage at further English intervention in Dutch politics: with precise timing, as Willem visited Amsterdam, Charles II published a letter claiming that English naval pressure would be lifted and that peace would prevail if Willem's rightful claims as stadholder were recognised. The English context raises further questions with regard to how nations represent and understand each other in literary works as well as to mutual Anglo-Dutch literary exchange. 


\section{$4 \quad$ Vondel and Oudaen: The Spectre of Palamedes}

Haagsche Broeder Moord was also, in a sense, about Vondel (by 1673 acknowledged as the preeminent Dutch poet-playwright) and about his place in Oudaen's writing and imagination: Vondel's own Remonstrant and then Roman Catholic sympathies, and his attacks on tyrants are well known. This is the case despite the confessional difference between the two men and their opposed views on the use of classical precepts. ${ }^{40}$ Oudaen's play is indebted to Vondel's Palamedes (1st edn. 1626), an allegorical account of the demise of Pensionary Jan van Oldenbarnevelt, a performance of which we know de Witt attended in $1662 .{ }^{41}$ Palamedes appeared as a character unjustly condemned to death in tragedies by Aeschylus, Sophocles, and Euripides; it was known in the seventeenth century that the story of Palamedes had been used by Euripides in an allegorical play on the death of Socrates. There had already been a Palamedes on the Dutch stage in the allegorical play Iphigenia (1617) by Vondel's associate Samuel Coster; the character had also been present in the visual iconography that represented the embattled Pensionary De Witt. ${ }^{42}$ Vondel presents Palamedes's death as a cannibalistic sacrificial meal, for he is literally torn apart by a furious mob and then has his blood drunk by Agamemnon (representing Maurits, the Prince of Orange), who begins the entire sequence of events 'greedily and so diabolically' ('En Agamemnon suypt verwoed | Sijn trouste raedsmans edel bloed'). ${ }^{43}$ Shockingly, Vondel portrays the rigors of

40 Melles, p. 123. For further evidence of both connections and tensions between Vondel and Oudaen, see Amy Golahny, 'Paired Poems on Pendant Paintings: Vondel and Oudaan Interpret Lastman', in The Eye of the Poet: Studies in the Reciprocity of the Visual and Literary Arts from the Renaissance to the Present, ed. by Amy Golahny (Cranbury, NJ: Associated University Presses, 1996), pp. 154-78.

41 I am indebted to the readings of Palamedes offered by Bettina Noak, 'Vondel as a Dramatist: The Representation of Language and Body' and Nina Geerdink, 'Politics and Aesthetics-Decoding Allegory in Palamedes (1625)', both in Joost van den Vondel: Dutch Playwright in the Golden Age (1587-1679), ed. by Jan Bloemendal and Frans-Willem Korsten (Leiden: Brill, 2012), pp. $115-38$ and 225-48, respectively.

42 See M.B. Smits-Veldt, Samuel Coster, ethicus-didacticus: Een onderzoek naar dramatische opzet en morele instructie van Ithys, Polyxena en Iphigenia (Groningen: Wolters-Noordhoff/ Forsten, 1986), chapter 5; Freya Sierhuis, The Literature of the Arminian Controversy: Religion, Politics and the Stage in the Dutch Republic (Oxford: Oxford University Press, 2016), chapter 3 .

43 Vondel, Palamedes (Amsterdam: Jacob Aerstz. Calom, 1625), p. 96. Translation by Noak, 'Vondel as a Dramatist', p. 134. 
Calvinist theology and its willingness to pursue its aims with arms against the Arminians as bloodthirsty primitivism. ${ }^{44}$ Palamedes and his violent tale prefigure Oudaen's portrayal of the De Witt brothers' murder, in which ancient ritual barbarism seems reborn.

Palamedes was censored, and since Vondel's name was on the title page, charges were brought against him. He went into hiding for fear of the sanctions of the severe Court of Holland in The Hague (the court that, in 1672 , would try Cornelis de Witt) but resurfaced after it became clear that the Amsterdam city government had refused to hand him over to The Hague. In fact, they had decided to prosecute him themselves. Since some of the Amsterdam city regents were kindly disposed to Vondel, he was treated leniently and was subjected to a fine of just three hundred guilders. The fact that Palamedes took the form of a play was used as an argument by some of the judges to regard it as open to manifold interpretations, rendering it not obviously intended as a political statement. For his part, Oudaen avoided censure simply by not appearing in court when summoned.

What could not be played in the Netherlands found reception elsewhere. Another play signed 'N.V.M.' and now attributed to J. Duym, Tragoedie van den bloedigen Haeg, ofte Broedermoort van Jan en Cornelis de Witt (The Bloody Hague Tragedy, or the Fratricide of Jan and Cornelis de Witt), was performed in Stockholm by a company from The Hague in 1674; in 1679 another performance at the Swedish court was prevented by the Dutch ambassador. ${ }^{45}$ This play, together with some illustrative engravings, was printed at Amsterdam and Antwerp in 1672. The difference between it and Oudaen's play is clear: a romantic sub-plot involves an imaginary lover (Frederick) of De Witt's daughter in political intrigues; one sees the devising and development of the conspiracy and the dubious role of the prince therein. The anti-Orangist scope of the drama addressed contemporary Swedish politics as well, and among the Dutch then resident in Scandinavia there were many republicans who feared the excessive power of the stadholder. The tragic demise of the Grand Pensionary and his brother was, for them, new proof of Orangist arbitrariness.

44 For recent readings, see Frans-Willem Korsten, Vondel belicht: Voorstellingen van soevereiniteit (Hilversum: Verloren, 2006), pp. 129-37; in English as Korsten, Sovereignty as Inviolability: Vondel's Theatrical Explorations in the Dutch Republic (Hilversum: Verloren, 2009), pp. 119-25.

45 See Noak, Politische Auffassungen, pp. 235-36. 
Oudaen's ultimate testimony to the tradition of religious toleration was his truer-spel (tragedy) of 1655 , Servetus, which is concerned with the very same martyred Spanish anti-Trinitarian Miguel Servet (1509/11-1553) who figured so prominently in the great sixteenth-century Dutch tolerationist Dirck Volkerszoon Coornhert's Synodus of tusshcen de ende nieuw. Vander conscientien vryheyt (Synod on the Freedom of the Conscience). ${ }^{46}$ Alas, only one act (the last one) survives, although I am beginning to think that this is all there ever was of what in part is also a morality play (Zinnespel), which also means 'concern with the distinction between good and evil or right and wrong. The single act is mostly a dialogue between the suspiciously named 'Vatikanus' and 'Blandrata', the latter based on the real Giorgio Biandrata or Blandrata (1515-1588), Italian physician and polemicist, follower of Servetus, and perennial anti-Trinitarian, whose published works were compressed versions of Servetus's major work Christianismi Restitutio (1553). Blandrata played a major role in introducing anti-Trinitarianism to Transylvania and was especially good at making Calvinists anti-Trinitarian; his character in the play speaks about what he regards as the loathsome hypocrisy of Calvinism. ${ }^{47}$

Oudaen's character Blandrata is also keen to reveal the hypocrisy of Jean Calvin (1509-1564), whose public humility regarding the condemnation and burning of Servetus masked triumphal laughter-a damnable offence in Blandrata's view. Calvin's infamous letter to his fellow reformer Guillaume Farel (1485-1565), in which he wrote that if Servetus came to Geneva he (Calvin) would not let him leave alive, is dramatically represented. ${ }^{48}$ The letter is cited in a footnote in the text: here Oudaen performs his function of openly revealing that which had been secret (in keeping with the genre of the 'secret history'). ${ }^{49}$ His footnote cites Grotius (Hugo Grotius or Hugo de Groot, 15831645), friend of the Remonstrants and exile to Paris in the 1620 ), on whose testimony the existence of the letter in the Royal Library in Paris was confirmed. ${ }^{50}$ There was a determined attempt to keep the letter secret; it was finally made

46 First published in print in Joachim Oudaen, Tooneelpoëzy (Amsterdam, 1712), pp. 261-81.

47 See Sergio Carletto and Graziano Lingua, La Trinità e l'Anticristo: Giorgio Biandrata tra eresia e diplomazia (Dronero: L'Arciere, 2001).

48 For Farel, see Jason Zuidema and Theodore van Raalte, Early French Reform: The Theology and Spirituality of Guillaume Farel (Farnham: Ashgate Publishing Limited, 2011).

49 See Annabel Patterson, 'Marvell and Secret History', in Marvell and Liberty, ed. by Warren Cherniak and Martin Dzelzainis (Houndmills: MacMillan Press, 1999), pp. 27-29.

5o Oudaen, Tooneelpoëzy, p. 272. 
fully public in Antoine Varillas's 1686 history of religious revolutions (and here we should remember that Servetus, like Haagsche Broeder-Moord, did not circulate in print until 1712). ${ }^{51}$ Farel becomes Calvin's tool in the reported action, demanding that Servetus speak to the Genevan people while the scene of execution is prepared and described in graphic detail: the 'murder pole', the chain that binds the victim to the pole, and the blue and purple striped robe that Servetus was required to wear. ${ }^{52}$ The faggots are lit and Servetus screams as he feels the heat; then we hear a far coarser voice, choked with smoke, as he calls on his Redeemer. Shortly thereafter, Servetus is cooked black like coal. Only his gold chain remains, glowing in the charred ruins of his body. ${ }^{53}$ As Servetus's soul makes its journey heavenward, the allegorical figures of Resentment and Envy feast on his remains. ${ }^{54}$ It is in Vatikanus's interest to show that Geneva is far worse than Rome. He admonishes Blandrata not to call down holy vengeance from God; Blandrata's reply is that God will act in his own time when he is good and ready. .5

It would be natural to see the play as part of the inter-confessional martyrdrama wars of early modern Europe that were so capaciously analysed by Alison Shell in her earlier work. ${ }^{56}$ And indeed, here we do have anti-Trinitarian and Roman Catholic debaters, concentrating the confessional clash within a single play even as it is a vilification of magisterial Protestantism and Calvin in particular. That would be fine were it not for the fact that Oudaen is so strongly linked with the fierce drama of the earlier Schouwburg years. Moreover, how could Servetus not be seen as a development of and reaction against a slightly earlier martyr play like Vondel's Maria Stuarta of Gemartelde majesteit (Mary Stuart or Martyred Majesty, 1646), which had occasioned a direct response from Oudaen in Johanna Grey of gemartelde onnozelheyd (Jane Grey or Martyred Innocence, 1648)? In the 1640 , soon after Vondel converted to Catholicism in 1640-1641, his plays hit on the martyr theme, an account of tragic death that was both confessional and part of the high politics of post-Reformation Europe. Mary Stuart or Martyred Majesty (1646) presents Mary Queen of Scots as the

\footnotetext{
$5^{1}$ Antoine Varillas, Histoire des Revolutions arrivées dans l'Europe en Matiere de Religion, 6 vols (1686).

52 Oudaen, Tooneelpoëzy, pp. 266-67.

53 Ibid., pp. 267-68: 'daar vat de vlam na't hart | En glenstert levend op; hy zwijmt, hy zakt ter neder, | Zoo zwart gelijk een kool [...] De yz're keten gloeyt, en fchijnt de goude keten, | Die op den boezen hing.'

54 Ibid., pp. 270-71.

55 Ibid., p. 276.

56 Alison Shell, Catholicism, Controversy, and the English Literary Imagination, 1558-1660 (Cambridge: Cambridge University Press, 1999).
} 
victim of a Machiavellian Elizabeth I and of international intrigue. ${ }^{57}$ Parallels with the plight of Charles I at this time are obvious: there is an open castigation of Puritanism in the play and, by presenting Mary as a latter day Christ, Vondel was affirming his strong belief in divine right monarchy. James VI of Scotland, the future James I of England and Mary's son, is warned in the play to keep the Puritans in check; by 1646 it was known that Charles I, son of James VI and I, had consummately failed to do so (l. 1128). The First Anglo-Dutch War was five years in the future and Vondel was speaking against the official views of the Dutch Republic: he seemed to delight in these provocations. Perhaps we should not be surprised when we remember that religious controversy itself was no stranger to religious acting companies before the Dutch Revolt, so that some rhetorical societies in the Netherlands were populated by majorities of both Lutherans and Anabaptists. ${ }^{58}$ Vondel is not, however, uncritical of Mary, and clearly sides with the rational analysis of her predicament and with the free will that we see her exercise-as opposed to the blind partisanship and bigoted intolerance of her chaplain. ${ }^{59}$

Servetus was notorious as an anti-Trinitarian (among several other heterodox views he held) and Oudaen's play offers a radical religious critique of the persecution of heresy by magisterial Protestantism. ${ }^{60}$ To that end he calls upon a Netherlands tradition of martyrdom in the name of faith that was a quintessential part of Anabaptist and Mennonite identity. By virtue of his birth, Vondel would also have been deeply familiar with it. ${ }^{61}$ Yet in their plays that refer to

57 For a translation, see Joost van den Vondel, Mary Stuart or Tortured Majesty, trans. with introd. and notes by Kristiann P. Aercke (Ottawa: Dovehouse Editions Inc., 1996).

58 Gary K. Waite, Reformers on Stage: Popular Drama and Religious Propaganda in the Low Countries of Charles V, 1515-1556 (Toronto: University of Toronto Press, 2000), pp. 127-29. See also Wim Hüsken, "Heresy" in the Plays of the Dutch Rhetoricians', in Urban Theatre in the Low Countries, 1400-1625, ed. by Elsa Stretman and Peter Happé (Turnhout: Brepols, 2006), pp. 103-24.

59 For many of the European plays concerned with Mary Stuart's execution, the sympathy of the audience with the tragic queen was overwhelming; for another, more equivocal perspective, see Christophorus Kormart, Maria Stuart Oder Gemarterte Majestät (1673) and Joel B. Lande, 'German Trauerspiel and its International Nexus: On the Migration of Poetic Forms', in Politics and Aesthetics in European Baroque Tragedy, ed. by Bloemendal and Smith, pp. 319-43.

60 See also Bauke van Dam-Heringa, 'Oudaans socinianisme, met name in zijn Aandachtige Treurigheyd', De Nieuwe Taalgids, 77 (1984), pp. 484-92.

61 The definitions and interactions of early modern Roman Catholic, Protestant and Anabaptist versions of martyrdom, that is dying for and in the name of one's faith, usually as a result of religious persecution, literally embodying the word's original meaning as 'witness', is extensively analysed by Brad S. Gregory, Salvation at Stake: Christian 
political strife in the Dutch Republic, even though the issue at stake is religious (the Arminian controversy and the longer history of religious toleration), and even though there is forceful religious persecution (the Dutch Calvinists as well as the Prince of Orange), we are witnessing in Vondel's Palamedes and certainly in Oudaen's Haagsche Broeder-Moord what must be described as political martyr drama, presented in a distinctly civic context.

\section{Conclusion: Contexts for Oudaen's Drama}

We have seen how English events are strongly present in Haagsche Broeder Moord, and there was much sympathy in the Netherlands for the plight of King Charles I, who was executed on 30 January 1649 and represented-by himself and his followers - as a martyr king: certainly a political martyr but also a simulacrum of Jesus, whose representative he was considered to be, as well as a kind of English Protestant saint. No one in the Netherlands (as opposed to a Dutchman in the employ of the English Republic in the Netherlands,

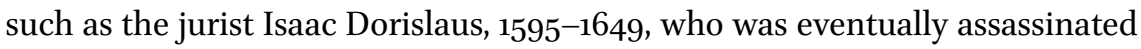
in The Hague by English Royalists) approved of the English regicide. It was universally condemned, even among the republicans; Paul Sellin and Helmer Helmers have accurately documented how widespread this disapproval was. ${ }^{62}$ Oudaen's Konradyn is his resistance to Oliver Cromwell. Karel Stuart (1652) by Jan Dullaert (1630-c. 1681), which is profoundly resonant with English royalism, is no less indebted to Vondel's Palamedes than is Oudaen's Haagsche Broeder-Moord. ${ }^{63}$ The Silesian playwright Andreas Gryphius also made dramatic capital from the English martyr kings with his 1657 trauerspiel entitled Carolus Stuardus, oder Ermordetete Majestät.

It could be argued that Vondel had by 1672 already outstripped Oudaen's martyr theatre in his attempt to present flawed heroes by employing classi-

Martyrdom in Early Modern Europe (Cambridge: Harvard University Press, 1999); see especially pp. $215-49$.

62 See, for example, Jan Dullaart, Karel Stuart, of Rampzalige Majesteit [Charles Stuart, or Catastrophic Majesty] (1652); Paul R. Sellin (with Margriet Lacy-Bruijn), 'Royalist Propaganda and Dutch Poets on the Execution of Charles I: Notes Towards an Inquiry', Dutch Crossing, 24 (2000), pp. 241-64; Helmer Helmers, 'The Cry of the Royal Blood: Revenge Tragedy and the Stuart Cause in the Dutch Republic', in Literary Cultures and Public Opinion in the Low Countries, 1450-1650, ed. by Jan Bloemendal, Arjan van Dixhoorn and Elsa Strietman (Leiden: Brill, 2011), pp. 219-50.

63 See Helmers, The Royalist Republic: Literature, Politics and Religion in the Anglo-Dutch Public Sphere, 1639-1660 (Cambridge: Cambridge University Press, 2015), p. 179. 
cal precepts. The question of will arises in Vondel's Lucifer (1654), a study in Edenic excellence and angelic inferiority:

Hoe arm is eenigheit! Wy kennen geen gespan

Van tweederhande kunne, een jongkvrouw, en een' man.

Helaes! Wy zyn misdealt: wy weten van geen trouwen,

Van gade of gading, in een' hemel, zonder vrouwen.

We're poorly off, alone and celibate-

Denied the joys of sex, the married state;

Deprived of consort, starved of loving tryst:

Some heaven, this—where women don't exist! ${ }^{64}$

Lucifer is called the 'lieutenant' ('Stedehouder') in the dramatis personae; he describes mankind as mere 'commoners'. Vondel was probably alluding to Willem II's attack on Amsterdam in August 1650, which would have been a major step towards total Orange sovereignty in the Dutch Republic, had it been successful. Rafael's position that 'Authority's not owned; it's delegated!' ('Geleende heerschappy staet los, en is geen erf!') also foreshadows the contestation of Orangist claims that Willem III was entitled to the offices and powers of his forefathers by birth. ${ }^{65}$

After he had mastered Latin around 1640, Vondel followed the Dutch scholarly commentators on ancient tragedy (in particular G.J. Vossius, 1577-1649) ${ }^{66}$ in order to fashion an even more narrowly focused printed tragedy (although Vondel treats the contents as performed action) that analyses the exquisite pain of its protagonists. These include Jeptha, the eponymous subject of a 1659 tragedy, the Israelite hero who condemned his daughter to death by vowing, in thanks to God for a victory over the Ephraimites, to sacrifice the first thing he sees upon his return to his city. ${ }^{67} \mathrm{He}$ sees his daughter, keeps his word (despite mitigating arguments from a priest), and proceeds to lose his daughter, his wits, his reputation, and finally his life. In his preface and throughout, Vondel

64 Joost van den Vondel, Lucifer (1654), p. 5; Lucifer, trans. by Noel Clark (London: Oberon Books, 1990), p. 17 .

65 Vondel, Lucifer, p. 44; trans. Clark, p. 61.

66 See the magnificent edition of Vossius's Poeticarum institutionum libri tres, ed. by Jan Bloemendal, with English translation, 2 vols. (Leiden: Brill, 2010).

67 Joost van den Vondel, Jeptha of Offerbelofte (1659), ed. by N.C.H. Wijngaards (Zutphen: W.J. Thieme \& CIE, 1972, rev. edn 1977); see also Koning David hersteld and Faëton, of roekeloze stoutheid, ed. by J.W.H. Konst (Amsterdam: Bert Bakker, 2004). 
maintains that his play is 'appropriately proportioned' in order to maximise 'powerful emotional effect' ('Het spel heft zijne behoorlijcke hoegrootheid, en leden, met de maete van evenredenheit gemeeten'; 'maghtige beweeghenisse te baeren'). Jeptha must exist in a state between 'pious and impious, which is actually the quality required of the main character of a perfect tragedy' ('vroom en onvroom, eene hoedanigheit eigentlijck in een personaedje vann een volkomen truerspel vereischt'). ${ }^{68}$ Vondel is instead contributing to the formation and development of uniquely Dutch classical drama, following a tradition of scholarship that had settled strongly and distinctively in Holland, and his narrative may be said to assert an ideological plea for Catholic level-headed discipline (exemplified by the Israelite priest and arch-priest- the mitigating voices of traditional authority) over and against the claims of destructive Protestant personal conscience (as represented by Jeptha). Calvinism was the public, if not established, religion of the Dutch Republic. Vondel had found a way of commenting upon contemporary politics without staging literal history, thereby creating artistic freedom for himself and interpretative liberty for his audience or readers, and replacing martyrdom with a meditation on the theme of sacrifice and the nature of human will.

We have already seen that Oudaen was a Collegiant, and noted the relatively non-exclusive, non-binding nature of Collegiant association. ${ }^{69}$ A Collegiant principle, from the beginning, had been to admit to their society all individuals who were willing to acknowledge their belief in the Bible as inspired scripture. No confession of faith was required, and the widest diversity of opinion was permitted. Baruch de Spinoza, member of the Jewish community, lens grinder, and challengingly original philosopher, joined the study groups of the Collegiants at Rijnsberg while living near Leiden from 1660 to 1663 . By the end of the seventeenth century, his opinions had obtained a strong hold upon the Collegiants and caused a temporary division of their members into two parties, with separate places of meeting.

It is not difficult to see how Oudaen, active in the Rotterdam Collegiant community, would have prevailed in it in terms of his own beliefs. Not surprisingly, he denounced Hobbes's views and also refuted Spinoza. ${ }^{70}$ In 1675 , just two years after writing Haagsche Broeder-Moord, Oudaen published a Dutch

68 'Joost van den Vondel's Jephtha', trans. by Peter King, Dutch Crossing, 32 (2008), p. 185; 'Berecht' [literally 'trail'; as in 'discussion', standing for 'Preface'] in Vondel, Jeptha, ed. by Wijngaards, pp. 34-35.

69 See notes $5^{-6 .}$

70 See Joachim Oudaen, 'Aan Adriaan Verwer of Zijn Werk. De atheisterij het mom-aanzicht af-gelicht; of Wedderlegging de Zedekunst van B. Spinoza', in Melles, pp. 191-93. 
translation of Sir Edwin Sandys's comparative study of European versions of Christianity, which was one of the century's most influential motors of free thinking and deism; initially assembled in Venice with the help of Paolo Sarpi, it first appeared, without Sandys's permission, as A Relation of the State of Religion: and with what Hopes and Pollicies it hath beene framed, and is maintained in the Severall States of these Westerne Parts of the World (London, 1605). ${ }^{71}$ I suspect Oudaen was most interested in the exposure of Roman Catholicism that was offered by Sandys; that he translated it from the French underlines his distance from English culture. Yet clearly the challenge represented by Spinoza's decoupling of the Bible from philosophy was in quite another league, enforced as it was by his gleanings from Descartes and Hobbes.

In this context we can see that Oudaen's career and works sit very close to but are not identical with associations in the Netherlands that seem to cut free from conventional belief, move into philosophy, and assert a critique of scripture in terms that, in England or France at this time, are only ever offered in theistic terms. For example, Franciscus Van den Enden (1602-1674) was a sometime Jesuit, neo-Latin poet, physician, art dealer, philosopher, and plotter who taught Spinoza in his Latin school on the Singel in Amsterdam in the late 165 os. $^{72}$ From this school, Van den Enden had his pupils perform several Latin dramas in the Schouwburg as well as his own Latin play, Philedonius (1657), an allegory of virtue deploying alchemical symbolism based on the Table of Cebes. ${ }^{73}$ In a prefatory poem, Vondel strongly recommended Philedonius. Like the martyr hero in Oudaen's Servetus, Van den Enden was seen as an atheist by some and as a Roman Catholic by others. With Pieter Corneliszoon Plockhoy (c. 1625-c. 1664/70) another Mennonite Collegiant who sought permission

71 Edwin Sandys, Verhaal van den staat der religie: Waar in te zien is met hoedanige voornemens, en listigheden, de zelve toegestelt, en beleid word, in verscheyde staaten van de westersche deelen des werelds, trans. by Joachim Oudaen (Harlingen, 1675).

72 Readers should know that the origins of this paragraph and my first encounter with Van den Enden was in Jonathan I. Israel, Radical Enlightenment: Philosophy and the Making of Modernity 1650-1750 (Oxford: Oxford University Press, 2001), pp. 169-84. See also Franciscus van den Enden, Free Political Propositions and Considerations of State (1665): Text in Translation, the Relevant Biographical Documents and a Selection from Kort Verhael, ed. by Wim Klever ('Vrijstad' [Capelle a/d Ijssel], 2007).

73 Franciscus van den Enden, Philedonius, ed. by Marc Bedjaï (Paris: Kimé, 1994); Franciscus van den Enden, Philedonius, 1657: Spinoza, Van den Enden e i classici latini, ed. by Omero Proietti (Macerata: EUM, 2010). See also Frans-Willem Korsten, 'Mundus Dramaticus: A School Drama and Dramatization-Franciscus van den Enden', in Drama, Performance and Debate: Theatre and Public Opinion in the Early Modern Period, ed. by Jan Bloemendal, Peter G.F. Eversmann, and Elsa Strietman (Leiden: Brill, 2012), pp. 311-33. 
from Oliver Cromwell to establish utopias in England), Van den Enden worked on a project for a utopian settlement in New Netherland, on the present Delaware shore, and developed views of this ideal society in his Kort Verhael van Nieuw-Nederland (Brief Account of New-Netherland, 1662). He was plainly against slavery. In 1665, Van den Enden's Vrye Politijke Stellingen (Free Political Propositions) defended democracy and gave the state social and educational tasks. In 1671, he moved to Paris where he opened another Latin school, was unfortunately implicated in a plot to establish an aristocratic republic in Normandy, and was ignominiously hanged in front of the Bastille after the decapitation of the noble conspirators. It is almost a surprise that the republican and tolerant, if still religious, Oudaen did not write a play about him.

The achievement of Dutch literature seems - while undoubtedly embodying and participating in the advanced form of mercantile life afforded by the rise of the United Provinces in a way that seems similar to the development of both consciousness and artistic achievement in the Italian city states of the later fifteenth and earlier sixteenth centuries - to be that high literary art is both expression and, again, embodiment of what was considered most valuable about life in the republic: liberty and toleration. Joachim Oudaen was at the centre of this achievement, and he was profoundly influenced by (although he ultimately departed from) Joost van den Vondel. While never entirely separating the figure of the martyr from religious concerns, in locating the martyr as a consequence of political violence, and while seeing very little of his drama performed on stage, Oudaen gave vital theatrical embodiment to the tensions at the heart of the republic's fractious political life.

I do not think that there is any comparable achievement in any other European vernacular literature at this time. English drama, before the theatre closure of July 1642, offered political views at the behest of powerful aristocratic patrons; this was exaggerated when the theatres reopened in 1661; Milton struggled to find the kind of context for his art that Vondel, Oudaen, and their fellow writers enjoyed; the English republicans could only imagine the kind of theatre afforded by the Schouwburg, however difficult it was to mount a contentious play in Amsterdam. In France, a powerful administration meant that many advanced kinds of literary innovation took place in the service of an absolutist monarchy enforced by the church: alterity and critique was censored and persecuted $c .1615^{-1630}$ and then became implicit if not completely under wraps. Oudaen's drama embodies in its very form the passage from a society in which the most violent persecution of religious belief was considered legitimate and normative to a tolerant society; from uniformity enforced by princely and clerical authority, even to the point of war, to a mercantile and artistic prosperity based upon peaceful trading and the open 
exchange of views, values, and truth standards. Those who preferred neoclassical patterns to this violent drama might be seen to have been attempting to repress or forget difficult tensions that remained unresolved at the heart of the Dutch Republic's polity. These are tensions that resonate throughout early modern European and colonial history and come down to us today. For these reasons Dutch drama deserves to be far better known than it is, to be juxtaposed far more effectively with Marlowe, Shakespeare, Jonson, Corneille, Racine, Calderón, Lope de Vega, and all the rest, and to be performed again, in the name of a vigorously revived international civic theatre. The theatre and commitments of Dario Fo come to mind. 